\title{
Valstatistik i bruk. Socialdemokratin, väljarna och den osäkra demokratin I9I2-I929
}

\author{
Petter Tistedt
}

SAMMANDRAG: Redan långt före opinionsundersökningar och samhällsvetenskaplig valforskning fanns en annan politiskt användbar kvantitativ kunskap om väljare: officiell valstatistik. När rösträtten och därmed elektoratet snabbt utvidgades i början på I900-talet väckte denna kunskap påtagligt intresse. Petter Tistedts artikel utforskar hur tre ledande svenska socialdemokrater - Rickard Sandler, Gustav Möller samt Per Albin Hansson - gjorde bruk av valstatistik under partiets och den svenska demokratins genombrottstid. Studien visar hur denna kunskapsform inte tänktes tillhandahålla en redan färdig, politiskt neutral blick på valmanskåren. I stället behandlades den som ett ofullkomligt redskap som kunde omarbetas, kritiseras och bilda utgångspunkt för ny kunskap - eller avfärdas. Som sådan drogs den in i centrala diskussioner om socialdemokratins representativa anspråk och dess långsiktiga strategier för parlamentariskt maktövertagande.

NYCKELORD: valstatistik; elektorat; väljarkår; valmanskår; väljare; socialdemokrati; Socialdemokraterna; Rickard Sandler; Gustav Möller; Per Albin Hansson.

PUBLICERINGSHISTORIK: Originalpublicering.

PETTER TISTEDT är forskare i idé- och lärdomshistoria vid Uppsala universitet.

E-POSTADRESS: petter.tistedt@idehist.uu.se

FÖRSLAG PÅ KÄLLANGIVELSE:

Tistedt, Petter (2020) "Valstatistik i bruk. Socialdemokratin, väljarna och den osäkra demokratin I9I2-1929", i Arkiv. Tidskrift för sambällsanalys, nr I2, s. 6I-93. DOI: https://doi.org/I0.13068/2000-6217.12.2

(C) Petter Tistedt/Arkiv förlag \& tidskrift 2020 (publicerad I6 juni 2020)

Artikeln distribueras enligt en upphovsrättslicens från Creative Commons:

Erkännande-Ickekommersiell-IngaBearbetningar 3.0 Unported, som medger fri ickekommersiell användning och spridning i oförändrat skick så länge källan anges. 
Arkiv. Tidskrift för samhällsanalys är en sakkunniggranskad vetenskaplig tidskrift för samhällsvetenskap och historia. Samtliga artiklar publiceras fritt tillgängliga på:

$$
\text { www.tidskriftenarkiv.se }
$$

Beständig länk, DOI: https://doi.org/IO.I3068/2000-62I7

Den här artikeln finns tillgänglig i följande format:

PDF: via beständig länk, DOI: https://doi.org/IO.13068/2000-6217.12.2 TRYCK: ingår i bokutgåva av numret, ISBN: 978 9I 79243388

Grafisk utformning och sidnumrering är identisk i pdf och tryck.

Samtliga artiklar i nr I2 (2020) nås via beständig länk, DOI: https://doi.org/IO.I3068/2000-6217.I2

Arkiv. Tidskrift för samhällsanalys ISSN: 2000-62I7 (för elektronisk resurs) ISSN: 2000-6225 (för tryckta nummer)

ges ut av

Stiftelsen Arkiv för främjande och spridning av samhällsvetenskaplig och historisk forskning

\author{
genom \\ Arkiv förlag \& tidskrift \\ Box 1559 \\ SE-22I OI Lund \\ BESÖK: L Gråbrödersg 3 c, ipg \\ TEL: 046-I3 3920
}

ARKIV FÖRLAG: arkiv@arkiv.nu·www.arkiv.nu

TIDSKRIFTENARKIV: red@tidskriftenarkiv.se·www.tidskriftenarkiv.se

ANSVARIg UTGIVARE \& CHEFREDAKTÖR: Sven Hort

ADMinistratiV RedaKtör: David Lindberg Redaktörer: Paavo Bergman, Per Dannefjord, Lisa Kings,

Zhanna Kravchenko, Anna-Maria Sarstrand Marekovic 


\title{
Valstatistik i bruk. Socialdemokratin, väljarna och den osäkra demokratin I912-I929
}

\author{
PETTER TISTEDT
}

\section{Det svårfångade folket}

I en demokrati styr folket över sig självt. Men det är långt ifrån självklart vad "folket" är och hur det blir till, det visar såväl historiska undersökningar som samtida politisk teori. ${ }^{\text {I }}$ Detta är inte endast en semantisk fråga som kan lösas med allt bättre definitioner. En inflytelserik del av forskningen argumenterar övertygande för att demokratins "folk" inte finns till innan det representeras, eller med andra ord att det inte finns oberoende av de praktiker och institutioner som definierar, uttolkar, avbildar och gör anspråk på att företräda det. Dess karaktär fortsätter följaktligen att vara undflyende och omtvistad. ${ }^{2}$ Det minst undflyende sättet som "folket" framträder på, regelbundet om än kortvarigt, är sannolikt vid valurnorna. Där visar sig folket som elektorat - lätt att räkna och framställa i siffror, med direkta konsekvenser för politisk representation. ${ }^{3}$ Men som vi påminns om vid varje val är "folket" inte ens här någon enkel enhet med en lätt uttydd vilja, och när det ska studeras faller det till synes naturligt isär i mängder av politiska, sociala och ekonomiska kategorier. ${ }^{4}$

I. För en introduktion, se Canovan 2005.

2. Se t.ex. Olson 20i6; Frank 20Io; Rosanvallon 2006.

3. Rosanvallon 20II, s. I30-I3I.

4. Om det vittnar även vår tids debatter om pluralism och populism, exv. Müller 20 i6. 
Det är användningen av sådan kunskap om det väljande folket, under en tid av hastig demokratisering av den svenska politiska representationen, som står i fokus för denna undersökning.

När rösträtten och därmed elektoratet snabbt utvidgades - i Sverige mer än sexdubblades de röstberättigades antal mellan 1908 och I92I blev en rad frågor angelägna att besvara för politiker och politiska partier: Vilka var väljarna, hur valde de och vilka slutsatser kunde dras av detta för politiska program, strategier och mobiliseringsformer? Såväl moderna opinionsundersökningar som samhällsvetenskaplig valforskning låg ännu i framtiden. Något som däremot fanns var valstatistik, i Sverige insamlad och publicerad av statliga Statistiska centralbyrån (SCB) ända sedan tvåkammarriksdagens tillkomst I866.

Detta material har i efterhand bearbetats av forskare för att klarlägga förändringar i valmanskårens sammansättning och beteende. ${ }^{5}$ Här är jag i stället intresserad av hur valstatistik togs i bruk som en politisk resurs i sin omedelbara samtid, vilket även internationellt är nästan helt outforskat. Hur användes denna kunskap om det väljande folket? Hur bearbetades och kritiserades den? Hur analyserades och framställdes demokratins folk med hjälp av den? Denna artikel bidrar till att besvara dessa frågor genom en rad nedslag i socialdemokratisk debatt under knappt två decennier, från I9I2 till I929. På en mer generell nivå syftar artikeln därtill till att utforska samproduktionen av statistisk kunskap, politiska kategorier och partistrategiska överväganden.

\section{Valstatistik som kunskapsform}

Innan jag utvecklar detta vill jag säga något kort om valstatistikens distinkta karaktär. Intresset för att förstå "folket", ofta i en bredare mening än det faktiska elektoratet, var förstås en fundamental del i de diskussioner som - med ökad intensitet från slutet på ı8oo-talet - fördes om rösträttsbestämmelserna eller mer allmänt om den politiska demokratins eventuella företräden. Diskussionerna om vilka som egentligen hade eller kunde tillägna sig de förmågor som krävdes för att delta i politiken och bidra till viktiga samhällsfrågor avstannade inte heller efter

5. T.ex. Lewin, Jansson \& Sörbom I972; Lindgren 2019. 
den allmänna och lika rösträttens införande. ${ }^{6}$ Det är välkänt hur tidens populära masspsykologi bidrog till dessa diskussioner, särskilt i form av Gustave Le Bons Massans psykologi, i original från I895 och publicerad på svenska I9I2 i efterdyningarna av den reform som kraftigt utvidgade rösträtten för män. Som kunskapsform var masspsykologin som regel konservativ, demokratikritisk och spekulativ, och den satte fokus på de upplevda farorna med "massorna" - hur dessa utraderade individualitet och rationalitet, samt hur de tycktes lätt kunna manipuleras av skickliga ledare och propaganda. ${ }^{7}$ Valstatistisk kunskap var av ett annat slag. Den hade inget att säga om de röriga, oformliga, odifferentierade och potentiellt våldsamma grupper som masspsykologin beskrev och varnade för, utan berättade i övervägande tabellform om elektoratets agerande i allmänna val och behandlade därmed folket i dess laggivna kapacitet att auktorisera politiska representanter.

Valstatistiken var således empirisk och kvantitativ snarare än spekulativ och kvalitativ, och den tog inte direkt ställning till vad som påverkade elektoratets medlemmar att fatta sina beslut. I linje med annan officiell statistik syftade den från början till att - i liberal anda - öppna upp samhället för medborgerlig granskning och bidra till att ge underlag för bedömningen av genomförda och föreslagna reformer. ${ }^{8}$ Slutsatser och bearbetning lämnades samtidigt i hög grad över till läsarna.

Elektoratet stod i centrum så till vida att valstatistiken dokumenterade hur rösterna fördelade sig på olika partier och i olika delar av landet, hur kvarvarande rösträttsstreck verkade och hur valdeltagandet såg ut i olika delar av valmanskåren. Med hjälp av en bearbetning av röstlängderna infördes i det sista fallet en betydelsefull innovation i och med I9II års andrakammarval, då väljarna för första gången delades in yrkesgrupper och tre klasser - efter 1928 kallade socialgrupper - och efter I92I års val lades kön till som ytterligare kvalifikation. I och med detta kunde skillnader i valdeltagande tydliggöras. ${ }^{9}$

6. Se t.ex. Lundberg 2007; Rönnbäck 2004; Tistedt 2013.

7. Le Bon I9I2; Källström 1995 placerar in Le Bon i en svensk kontext.

8. Se motiveringarna i SCB I873, s. I; Berg I870, s. I73-I74.

9. Valstatistiken publicerades från och med 1873 i serie R i Bidrag till Sveriges officiella statistik och från och med I9I2 i Sveriges officiella statistik. Allmänna val. 
Att dela in elektoratet efter yrken och klasser var inte unikt för den svenska valstatistiken, men en påtagligt ovanlig företeelse och avgörande för de socialdemokratiska debatter som denna undersökning tar sin utgångspunkt i. ${ }^{\text {IO }}$

\section{Historiska perspektiv på kunskaper om väljare}

De former av kunskap om väljare som föregick moderna opinionsundersökningar och valforskning har inte ägnats mer än ett mycket måttligt historiskt intresse. Att det är ett potentiellt givande empiriskt forskningsområde står ändå klart. Exempelvis har Benjamin Schröder visat hur allmän rösträtt införde nya osäkerhetsmoment i brittisk och tysk politik, vilka krävde ny kunskap om väljarna och deras politiska preferenser, inte minst i form av partiers egna kartläggningar av potentiella väljare. ${ }^{\text {II }}$ Wim de Jong och Harm Kaal har visat hur samhällsvetenskaplig kunskap om elektoratet i Nederländerna sedan sekelskiftet 1900 har framställt föränderliga föreställningar om politisk representation samt varit en del av förvetenskapligandet av den politiska sfären. ${ }^{12}$ Förutom korta omnämnanden är dock officiell valstatistik frånvarande i denna forskning. ${ }^{13}$ Det studierna sammantaget ändå pekar på är att uppgifter om elektoratet - statistiska, geografiska, psykologiska - kunde efterfrågas och brukas för praktiska syften, särskilt valkampanjer, och att den också kunde få konsekvenser för politiskt tänkande, inklusive för förståelser av relationen mellan folk och folkvalda.

Fortfarande saknas däremot mer grundliga studier av hur kunskap om väljare användes och omarbetades under perioden samt hur ett sådant bruk var integrerat med såväl praktiska som mer politiskt-teoretiska överväganden. Perspektivet här är hämtat från den statistikforskning som betonar symbiosen mellan siffror och politik samt den forskning som undersöker kunskap i samhället som en fråga om cirkulering snarare än spridning.

IO. Tingsten 1937, kap. III; även Therborn 1984, s. 22.

II. Schröder 20I5; se även Beers 20II; Wring 2005, s. 37-42.

I2. de Jong \& Kaal 2017.

I3. Valstatistik är även frånvarande från den statistikhistoriska forskningen, se Tistedt 2019; Tistedt 2020. 
Som William Alonso och Paul Starr noterat är även officiell statistik politiserad, men inte nödvändigtvis i betydelsen korrumperad, utan av den anledningen att "politiska bedömningar är implicita i valet av vad som ska mätas, hur det ska mätas, hur ofta det ska mätas och hur resultaten ska presenteras och tolkas" ${ }^{14}$ Nikolas Rose har lagt till att det inte bara är fallet att "siffrornas domän är politiskt sammansatt" på det sätt Alonso och Starr beskriver, utan "dessutom skapas politikens domän med siffror" ${ }^{.5}$ Till denna numeriskt upprättade politiska domän hör elektoratet, och för att återknyta till inledningen: även som sådant är det demokratiska folket i behov av att definieras, uttolkas och representeras. Den kunskapshistoriska forskningen har vidare tydliggjort att kunskap - i vid bemärkelse och inklusive det de historiska aktörerna själva betraktade som välgrundat om än inte obestridligt vetande - alltid är i rörelse mellan olika sammanhang och bör förstås i termer av kontinuerlig omvandling, förändring och kontrovers snarare än avskild produktion och passivt mottagande. ${ }^{16}$ De socialdemokratiska debattörernas omarbetning av SCB:s siffror och kategorier bör således inte förstås som en illegitim politisering eller förvanskning av redan färdig kunskap, utan som ett led i dess fortsatta konstruktion och tillblivelse.

\section{Nedslag i socialdemokratisk debatt}

I syfte att utforska detta bruk av statistisk kunskap om elektoratet under det demokratiska genombrottets decennier gör artikeln tre nedslag, centrerade kring texter av Rickard Sandler 19I2, Gustav Möller I9I8 samt Per Albin Hansson 1929. Även företrädare för andra partier, liksom journalister och statsvetare, fann SCB:s siffror användbara, men dessa socialdemokratiska debatter är ovanligt intressanta i detta sammanhang eftersom de så tydligt och avsiktligt grep in i och försökte begripliggöra och hantera den hastiga och ännu osäkra demokratiseringen, och därtill avsåg att dra ut konsekvenserna för det egna partiet, dess representativa anspråk och långsiktiga strategier för parlamentariskt maktövertagande. Vilka röstade på partiet, och vilka kunde eller borde göra det i framti-

I4. Alonso \& Starr 1987, s. 2.

I5. Rose 1999, s. 198; se även Crook \& O’Hara 20II samt Igo 2007, särskilt kap. 3.

I6. Se t.ex. Östling m.fl. 2018. 
den? Hur skulle man förhålla sig till eventuella möjligheter att bredda partiets tilltal utöver den klass som till synes naturligt stödde partiet? Frågor av detta slag ställdes SAP, liksom andra europeiska arbetarpartier, inför. Det svenska exemplet visar hur svaren på frågorna och de praktiska lösningarna på problemen inte endast behövde förhålla sig till socialistisk teori och samhällsförståelse utan även till befintlig kunskap om valmanskåren, inte minst i termer av klass. Mycket stod därmed på spel i bruket av valstatistiken.

Frågorna om hur, när och varför arbetarrörelsen, eller mer snävt SAP, övergav arbetarklassens revolution till förmån för en inkluderande parlamentarisk och pragmatisk reformism är klassiska i svensk historieforskning. ${ }^{17}$ Någon enighet om hur frågorna ska besvaras har inte nåtts, inte heller om hur de ska ställas. ${ }^{18}$ Klart är hur som helst att SAP redan från sekelskiftet (och särskilt från och med utvidgningen av rösträtten 1909) successivt breddade sitt tilltal, men också att någon enighet i partiet om denna utvecklings önskvärdhet, mål och betydelse inte var för handen. Denna utveckling, som kommit att omtalas som en förskjutning från "klassparti" till "folkparti", bildar här i första hand en kontext för tolkningen av empirin, snarare än ett studieobjekt i egen rätt. Men studien bidrar också med ny kunskap om hur statistik drogs in i dessa processer. Även i forskning om liknande förändringar i andra europeiska länder saknas detta. Den svenska socialdemokratins situation och utveckling var inte unik - ingenstans i Västeuropa kunde arbetarpartier vinna en parlamentarisk majoritet utan att söka stöd bland andra än en mer snävt definierad arbetarklass. ${ }^{\text {I9 }}$ Tidigare forskning har visat att arbetarpartier var upptagna med att kategorisera sina befintliga och önskade väljare inte minst efter kön, yrke och klass - samt med att utveckla och bredda sitt tilltal och representativa anspråk på sätt som inte bara appellerade till befintliga identiteter och intressen utan också skapade nya. ${ }^{20}$ Hur eller

I7. En fortfarande relevant översikt är Hilson 200I. Till bidrag som tillkommit senare eller av annan anledning inte nämns av Hilson hör Jansson 20I2; Dannefjord 2009; Karlsson 200I; Jonsson 2000; Berman 1998; Schüllerqvist 1992.

I8. Se t.ex. de kritiska perspektiven på frågan om "revolution eller reformism" i Linderborg 200I, exv. s. 442; samt Stråth 1986; jfr även Berger I995, s. 248.

19. Berger 1995, s. 252.

20. Se främst Kaal 20I3; Lawrence 20II; Black 2003; Childers I990. Jfr även not II ovan. För en belysande teoretisk diskussion av representativa anspråk, se Saward 2006. 
i vilken utsträckning detta arbete underbyggdes med statistiskt vetande om väljarna är dock mindre klart, trots forskningens starka intresse för hur språket inte endast avspeglar utan även formar den politiska sfären, och trots att statistiskt kategoriseringsarbete är ett närmast paradigmatiskt exempel på just detta.

Den följande undersökningen uppehåller sig vid valstatistiken i bruk, de problem eller angelägna frågor som valstatistiken användes för att lösa eller belysa, vilken uppgift den tänktes kunna fylla, men också hur dess begränsningar formulerades. Jag är alltså intresserad både av vilka slags politiska resonemang och strategier valstatistiken underbyggde och av hur och med vilka syften dessa kategoriseringar kunde omarbetas, undermineras och kritiseras. Avsikten är att visa på det konkreta arbetet med statistiken samt hur detta arbete fick betydelse genom att infogas i diskussioner om SAP:s målsättningar och relationer till valmanskåren, något som motiverar undersökningens få men relativt utförliga nedslag. Dessa nedslag bildar inte en sammanhängande berättelse, och ännu mindre ger de en uttömmande bild av Socialdemokraternas användning av valstatistik eller annan kunskap om elektoratet. Däremot kan de bindas samman med hjälp av befintlig kunskap om socialdemokratins historia och genom att visa några av de mest genomarbetade, kreativa och kritiska användningarna av valstatistiken under perioden ger nedslagen också en särskilt god ingång i undersökningens ämne. ${ }^{2 \mathrm{I}}$

Sandler, Möller och Hansson hade det gemensamt att de aktualiserade valstatistiken för att söka svar på för partiet centrala ideologiska och strategiska frågor, men de gjorde bruk av den på olika sätt och med olika syften och drog olika slutsatser. I de två senare nedslagen behandlar jag även den dagstidningspolemik som uppstod, i syfte att vidare belysa hur politiska ställningstaganden och målsättningar influerade bruket och bedömningarna av valstatistiken.

2I. Urvalet grundar sig i första hand på en genomgång av befintlig forskning om SAP samt dess tidskrift Tiden från dess start i I908 till 1933. Perioden har avgränsats utifrån intresset att fånga in diskussioner om såväl den breddade rösträtten som SAP:s rörelse mot idealet om ett folkparti. 


\section{Rickard Sandler och klassanalysens betydelse, I9I2}

När Rickard Sandler hösten I9I2 publicerade den första i en serie "reflexioner till valstatistiken" i den socialdemokratiska idé- och debatttidskriften Tiden tog han sin utgångspunkt i vad han uppfattade som en svaghet i diskussionerna om den så kallade genombrottsriksdagens resultat. Problemet var att bedömningarna inte utgick från "det faktiska maktläge" varur riksdagen framgått. Hans slutsats av det var att valmanskåren måste undersökas: "Varje omdöme om partiernas stora riktlinjer och allmänna kynne vilar på lösan sand, därest det icke utgår från kännedom om valmanskårens beskaffenhet." Det fordrades ett "faktamaterial", vilket hans reflexioner rörande "huvudmännen i svensk politik, väljarna själva” kunde bidra med. Detta ämne, fortsatte Sandler, var dessutom "av den art, att det även utan något särskilt behov att analysera riksdagsarbetets förutsättningar och resultat, påkallar socialdemokratins intresse". ${ }^{22}$

Den politiska situationen understryker det angelägna i Sandlers självpåtagna uppgift. "Genombrottsriksdagen" var förstås den första riksdag som sammanträdde efter reformerna 1907-1909, då vad som ofta kallades "allmän rösträtt" till andra kammaren infördes - för manliga medborgare. Valmanskåren hade mer än fördubblats, men även fortsättningsvis fanns ett antal rösträttsstreck kvar, av vilka det mest betydelsefulla var kravet att ha erlagt de tre senaste årens påförda utskylder till stat och kommun. Många arbetare föll för detta streck, men nyordningen var ändå avgörande.

Några utsikter att vinna en parlamentarisk majoritet med endast "arbetarklassen" som väljare fanns inte, men av det drog partiet inte slutsatsen att den parlamentariska vägen kunde avskrivas som en metod för att införa socialismen. Snarare blev möjligheterna att bredda stödet bland andra grupper en avgörande fråga. Redan tidigare hade partiet utökat sin agitation bland lantarbetare, småbrukarnas äganderätt hade förklarats legitim och i det nya partiprogrammet som antogs I9II inkluderas för första gången ett jordbruksprogram, samtidigt som det inte

22. Sandler i9i2a, s. 225 . 
längre endast talade om "arbetarklassens" utan om alla "de undertryckta klassernas" sociala frigörelse. ${ }^{23}$

I denna situation blev frågor om hur elektoratet kunde förstås i termer av klass, samt om kvarstående streck, valdeltagande och partiets klasskaraktär, högaktuella. För Sandler låg det nära till hands att ta sig an dem med valstatistiken som hjälp. Han var vid denna tid ledamot av SAP:s styrelse och av riksdagens andra kammare, samt lärare vid Brunnsviks folkhögskola i bland annat statistik. Senare skulle han bli chef för SCB, och tidigare hade han dokumenterat sitt intresse för att använda statistik såväl i valagitationen som i mer folkbildande sammanhang. I9ı publicerade han exempelvis valbroschyren Miljonärernas sambälle samt boken Sambället sådant det är, båda grundade i statistik och den senare med avsikten att för en "arbetarpublik [...] lämna brukbara vapen i kampen för 'samhället sådant det borde vara'. " ${ }^{24}$ Hans tilltro till statistikens möjlighet att begripliggöra samhällsfenomen i politiska syften var således uppenbar. Artiklarna i Tiden speglade detta, men de var också av en mer teknisk, strategisk och partiintern karaktär.

För Sandler hade valstatistiken stor potential, men den var inte oproblematisk. En grundläggande fråga var hur begreppet "klass" skulle förstås. Ett fundamentalt drag i politiken var den partibildning som skedde då grupper samverkade på grundval av gemensamma sociala intressen, och att "mer exakt fastställa dessa grupper är därför ett betydelsefullt steg fram mot en valstatistik, som ger den praktiska politiken verkligt värdefulla upplysningar och möjliggör en vetenskaplig analys av valhandling och valresultat”, skrev Sandler. ${ }^{25}$ SCB hade delat in väljarna i yrkesgrupper och sammanfört dessa i tre klasser: den högre klassen, medelklassen och kroppsarbetarnas klass. Men enligt Sandler gick det inte att se enligt vilken princip som fördelningen var gjord, eller om någon princip alls existerade. Centralbyrån hade kort sagt behövt "bättre klargöra den använda metoden och bättre fixera den använda terminologin". ${ }^{26}$

23. Se t.ex. Berman I998, s. 58-63; Gröning I988, kap. IV särskilt s. I25-I32; Simonson I985, kap. 7-8.

24. Sandler I9ııa, förordet; Sandler ı9ıьb; för en biografisk översikt se Norman (20002002).

25. Sandler i9i2a, s. 226.

26. Ibid., s. 226-228, citatet s. 226. 
Hur kunde något bättre åstadkommas? Sandler fick nu tillfälle att även påtala den schematiska syn på samhällets klassuppdelning som han menade präglade Socialdemokraterna. Att "tillnyktra" från uppfattningen att samhället endast består av två klasser var förutsättningen för att uppskatta den verkligt marxistiska uppfattningen "att nutida samhällsutveckling bestämmes väsentligen av de två stora klassintressena, mellan vilka icke bara ett tredje utan ett flertal andra klassintressen få allt svårare att balansera sig fram utan att söka stöd och ledning hos ettdera”. ${ }^{27}$ För Sandler erbjöd således statistiken inte ett färdigt verktyg att förstå samhället med, och den påkallade en rannsakan av de kategorier som Socialdemokraterna använde för att förstå samhället och dess samtida politiska dynamik. För att valstatistiken skulle vara riktigt användbar krävdes även att SCB:s klasskategorier omarbetades, men inte utifrån någon "kvasimarxistisk förenkling av klassmotsatserna" ${ }^{28}$

Som grund för omarbetningen av klassindelningen ställde Sandler två synpunkter mot varandra - socialekonomisk intresseriktning och levnadsstandard - och valde den förra. Valet grundades i en specifik förståelse av politikens och den politiska gruppbildningens natur:

Politik är rörelse, ej stillestånd. Och intresseriktningarna ge uttryck åt det dynamiska momentet, levnadsstandarden åt det statiska momentet i den sociala grupperingen. Det senare åskådliggör vad som är, det förra vart man vill. För politiken måste ju underlaget för strävandena vara det viktigaste. ${ }^{29}$

Sandler bestämde således väljarna som politiska subjekt och som objekt för kunskap genom att sammanföra dem i grupper med gemensamma, framåtsyftande intressen. Han tog han hjälp av Werner Sombart för att på grundval av "ekonomiska intressesamhörigheter och intressebrytningar" omstuva valstatistikens yrkesgrupper i "tre huvudklasser, vilka företräda olika ekonomiska system": det nuvarande privatkapitalistiska systemet, företrätt av kapitalistklassen; det tidigare härskande men fortfarande betydelsefulla system som karakteriserades av små självständiga näringsidkare, företrätt av medelklassen; samt framtidens socialistiska system, företrätt av underklassen, till vilken Sandler inkluderade

27. Ibid., s. 229.

28. Ibid., s. 229.

29. Ibid., s. 230. 
arrendatorer, torpare och jordbruksarbetare. Detta gav ett annat och mer användbart resultat än valstatistikens "sociala" och skenbart opolitiska indelningsgrund. ${ }^{30}$

Att detta resultat var betydelsefullt framgick av att det kunde användas för att belysa ett antal angelägna frågor. Till dessa hörde den sociala sammansättningen av vad Sandler kallade den "aktiva" respektive "passiva" valmanskåren, eller med andra ord valdeltagarna respektive de som föll för rösträttsstrecken eller valde att inte delta. Särskilt betydelsefullt var hur mycket olika klasser och yrkesgrupper hade vunnit eller förlorat i relativt inflytande till följd av streckens verkningar och valskolk, något som den officiella statistiken inte meddelade. ${ }^{31}$

Strecken framkallade en jämvikt mellan hemmansägare och arbetare, vilket förklarade liberalernas - hemmansägarintressets företrädare - ointresse av att avlägsna dem. ${ }^{32}$ Viktigare var dock att strecken, tillsammans med ett lågt valdeltagande $\mathrm{i}$ de grupper som drabbades hårdast av dem, innebar att underklassens relativa inflytande förvanskats med 8 till ıo procentenheter. "Att förvanskningen gått ut över socialdemokratin i första rummet är ju antagligt", konstaterade Sandler, med uppenbara implikationer för framtida prioriteringar. ${ }^{33}$ (Se vidare bild I nedan.)

För Sandler erbjöd siffrorna ingångar till ytterligare frågor av betydelse för partiets samhällsanalys, självförståelse och politiska strategier. En sådan rörde huruvida det förelåg en kvalitativ skillnad mellan den socialdemokratiska valmanskåren och partiorganisationen. Detta var viktigt att utreda på grund av förekomsten av en "schematisk föreställning" (även bland socialdemokraterna själva) om att "den socialistiska rösten är en arbetareröst" och omvänt att "arbetarerösten är en socialistisk röst". En sådan föreställning är farlig om den är osann, inskärpte Sandler. Åter igen kunde alltså valstatistiken vara en hjälp i att reda ut och kritisera en rådande men alltför enkel samhällsförståelse, som potentiellt hindrade partiets arbete: "Här är ett fall, där teorin verkligen skulle kunna göra praxis en tjänst", summerade han. ${ }^{34}$

30. Jfr SCB I9I2, s. 28-29.

31. Sandler i9i2a, s. 23I.

32. Ibid., s. 234.

33. Ibid., s. 234-235, citatet s. 235 .

34. Sandler I9I2b, s. 266. 
Uppgiften var inte lätt, men här kunde SCB:s siffror om valdeltagande i olika grupper kompletteras med Socialdemokraternas egna redan genomförda undersökningar, närmare bestämt rapporter från distriktsstyrelserna där de socialdemokratiska väljarnas fördelning på fyra större grupper uppskattades. Med hjälp av detta material kunde Sandler bland annat göra troligt att industri- och hantverksarbetarrösterna utgjorde 55,8 procent av alla socialdemokratiska röster, och att av alla valdeltagare i denna grupp röstade 63,7 procent socialdemokratiskt. ${ }^{35}$ En stor del av SAP:s röster kom med andra ord från annat håll än de arbetargrupper som Sandler kallade partiets "kärna" ${ }^{36}$ Detta resultat ledde vidare i ett ytterligare problem av stor principiell och praktiskt betydelse: om partiets medlemmar och dess väljare var så olika - vilka skulle riksdagsgruppen representera, medlemmarna eller väljarna? Faran låg i det förra fallet $i$ att väljarna inte fick det inflytande de borde ha, och i det senare fallet i att fraktionen i riksdagen blev alltför mäktig. I båda fallen hotade en utveckling mot oligarki. Svaret kunde därför, förklarade Sandler, vara varken det ena eller det andra: i stället måste partiet och dess väljare fås att sammanfalla. Häri låg en av det socialdemokratiska partiets "allra viktigaste uppgifter." ${ }^{37}$

Sandlers klassbegrepp - grundat i hans förståelse av politikens natur och läsningar av socialistisk teori, samt konkretiserat med statistikens yrkesgrupperingar - utgjorde den avgörande utgångspunkten i hans analys av det hastigt skiftande politiska landskapet under tidigt I9IO-tal. Den "folk"-terminologi som börjat göra sig gällande i socialdemokratiska diskussioner var frånvarande. Inga partier existerade "utanför eller över klasserna”, inget parti var "representanter för 'samhället' helt enkelt", utan endast för delar av detsamma, delar som sammanhölls av gemensamma intressen, inte gemensamma idéer. ${ }^{38}$ Den kunskap om elektoratet som SCB meddelade var inte färdig att användas innan dess "sociala" klassbegrepp reviderats i linje med detta. Sandler kunde inte undgå att reproducera centralbyråns yrkeskategorier som grund för klassindelningen, men hans reflexioner kring valstatistiken var också påtagligt produktiva i det

35. Ibid., s. 266-272.

36. Ibid., s. 265 .

37. Sandler I9I2c, citaten s. 3I3. Jfr Jonsson 2000, s. I33-I35.

38. Sandler igi2b, s. 264. 


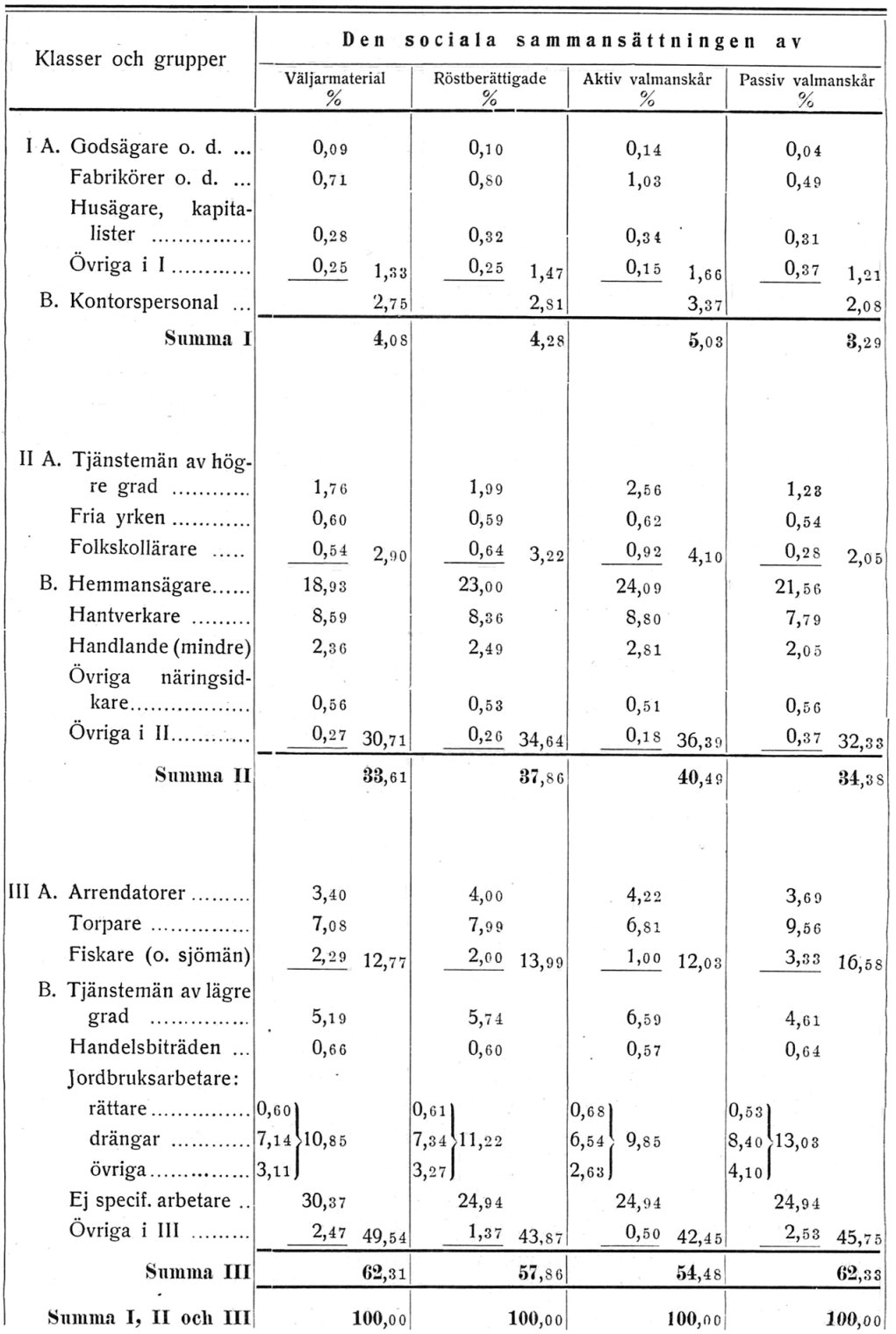

Bild I. Tabell ur Rickard Sandlers artikel "Valmanskåren. Reflexioner till valstatistiken. I" i Tiden nr 8 (I9I2a), s. 232. 
att han ändå kunde framställa ny kunskap om elektoratet samt göra konstruktiva inlägg i diskussioner om en rad teoretiska och praktiska frågor med implikationer för partiets politiska överväganden.

\section{Gustav Möller och socialdemokratins framtidsutsikter, I9I8}

När Gustav Möller publicerade sina egna "studier i valstatistiken” förklarade han det egna kunskapsintresset på följande vis: "Om man vill försöka bilda sig en konkret föreställning om socialdemokratins utsikter i vårt land torde bättre material än det vår officiella riksdagsstatistik erbjuder knappast stå till buds.” Även för Möller var det kategoriseringarna av valmanskåren som gjorde den så användbar: "Detta gör det möjligt att mäta samhällsklassernas styrka och att bilda sig en någorlunda riktig föreställning om de olika partiernas sociala underlag." ${ }^{39}$ Möllers motiveringar var däremot mer explicit framtidsinriktade än Sandlers. Nyckelordet var utsikter. Hans poäng var densamma som de följande åren gjordes i valagitationen: "En enig underklass erövrar lätt den politiska makten!" (I92I); Arbetarpartiet kan segra! Vad valstatistiken lär (1924). ${ }^{40}$

På I9IO-talet utmärkte Möller sig som en ideologiskt driven och teoretiskt intresserad skribent och redaktör, samt en viktig del i SAP:s högerflygel. ${ }^{4 \mathrm{I}}$ Möllers i historieforskningen ofta uppmärksammade bidrag till de socialdemokratiska debatterna om övergången till socialism, uppsatsen "Den sociala revolutionen" från I918, grundades delvis i hans tidigare studier i valstatistiken, publicerade på sensommaren samma år. ${ }^{42} \mathrm{De}$ senare är sällan ihågkomna i dag, men väckte desto mer uppmärksamhet i samtiden och blev - inte minst mot bakgrund av Möllers ställning som partisekreterare och redaktör för Tiden - föremål för omfattande dagstidningspolemik. SAP hade sedan årtiondets början fortsatt att bredda sitt tilltal till nya grupper och var - delvis på grund av splittringen året innan och till skillnad från tiden efter det misslyckade valet 1920 - ännu

39. Möller I9ı8a, s. I93.

40. Texten på en valaffisch från I92I, avbildad i SAP 1922 och här som bild 2 på nästa sida, respektive titeln på en valbroschyr, SAP i924.

4I. Möllers politiska verksamhet och tänkande behandlas i t.ex. Tilton I990, kap. 5 .

42. Möller i9ı8b. 


\section{Jämförelse mellan befolkningsklasserna i Sverige år 1920 .}

Den manliga befolkningens antal enligt röstlängderna.

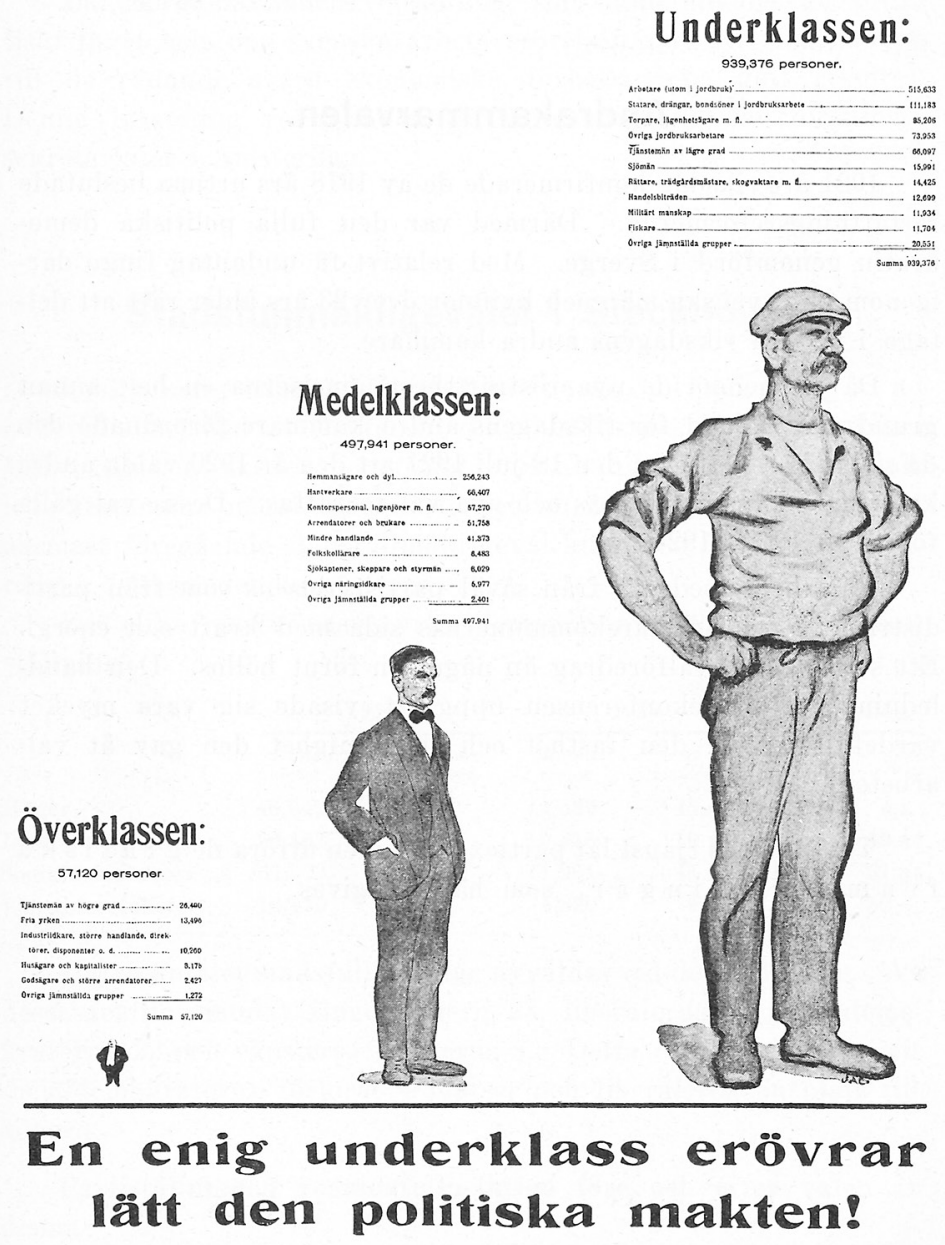

Bild 2. Affisch från valet 192I reproducerad i Socialdemokratiska partistyrelsens berättelse for år I92I (SAP 1922, s. 20). Byggd på en omarbetning av den officiella valstatistiken (bland annat har överklassen mer än halverats genom att gruppen "kontorspersonal, ingenjörer och verkmästare" flyttats till medelklassen). 
förhållandevis ideologiskt samlat och optimistiskt. ${ }^{43}$ Krigsslutet, de därmed associerade revolutionära stämningarna samt den mer verkligt "allmänna” rösträttens införande låg däremot ännu i framtiden.

Möller inledde sina studier i valstatistiken med att med hjälp av SCB:s yrkesgrupps- och klassindelning (av honom omdöpt till över-, medel- och underklassen) visa hur en liten minoritet hade oproportionerligt stor ekonomisk och politisk makt. Till de som "i verkligheten behärskar samhället" hörde mindre än I procent av den manliga befolkningen. ${ }^{44}$ Variationen mellan klasserna i valdeltagande och hur väljarna lade sina röster gjorde sitt till för snedfördelningen. Av valdeltagarna I9I7 tillhörde 53,I procent underklassen men endast 39, I procent röstade på partier som förde deras talan, medan det omvända gällde för överklassen: 8,7 procent respektive 24,7 procent. $^{45}$

Därmed var det grundläggande problemet beskrivet. För att bidra till lösningen skiljde Möller ut de delar av befolkningen vars sammantagna "politiska orientering och valdeltagande äro i ett demokratiskt samhälle avgörande för den politiska utvecklingen". De var avgörande därför att de var i majoritet: tillsammans omfattade de 78,4 procent av landets invånare. ${ }^{46}$ Möller avskrev således en minoritet som på sikt icke politiskt avgörande. I detta var SCB:s yrkeskategorisering fortfarande användbar, men inte dess tredelade klassindelning. Den relevanta majoriteten var dock heterogen, vilket motiverade att Möller i sin tur delade in den i bönder, jordbruksarbetare samt industri- och kommunikationsarbetare. ${ }^{47}$ Räknade man på dem visade det sig "att en allmän koalition mellan jordbrukets och industrins arbetare är tillräckligt för att giva arbetareklassens representation i andra kammaren majoritet”. ${ }^{4}$ Detta fick konsekvenser för Socialdemokraterna vad gäller vilka grupper partiet primärt borde företräda:

43. Se t.ex. Berman I998, kap. 5 särskilt s. III-II7; Gröning I988, kap. IV särskilt s. I32-I34.

44. Möller i9ı8a, s. i94.

45. Ibid., s. 195 .

46. Ibid.

47. Ibid.

48. Ibid., s. 197 . 
För att erövra majoriteten av valmännen behöver sålunda socialdemokratin icke taga särskild hänsyn till bönderna. Detta synes mig vara en fundamental politisk utgångspunkt för socialdemokratin, vilket vår rörelse har att fullt lära sig förstå. Socialdemokratin är och skall vara de egendomslösas, de utsugnas politiska parti. Allianser med besuttna klasser (såsom bönderna) äro därför icke naturliga; de kunna endast bliva av mycket tillfällig beskaffenhet. Däremot är åstadkommandet av en allians mellan alla egendomslösa klasser en naturlig strävan av ett socialdemokratiskt parti. ${ }^{49}$

Det är, konstaterade Möller, än så länge proletärer, främst jordbruksarbetare, som "upprätthåller det borgerliga väldet" genom att rösta på borgerliga partier. Jordbruksarbetarna spelar därmed "en fullkomligt avgörande roll för hela vår politiska och därmed för vår sociala utveckling." Dessa "underklassens efterblivna element" måste lösas "ur den borgerliga politikens bann", fastslog Möller. ${ }^{\circ 0}$

Sammantaget var slutsatserna påtagligt optimistiska, vilket de kunde vara om man som Möller förutsatte naturliga samband mellan klass, intresse och politiskt parti samt bortsåg från valsiffrorna och i stället tog fasta på klassfördelningen inom hela den politiskt myndiga befolkningen. Underklassen var inte bara den till befolkningstalet dominerande delen av befolkningen, den växte dessutom snabbare än andra klasser, den hade gemensamma intressen och en politisk rörelse som företrädde dessa. "Med de här påpekade sociala fakta för ögonen är det uppenbart, att högern för en hopplös kamp", summerade Möller, och fortsatte: "Om vi lugnt och objektivt vilja söka bedöma förhållandena, måste vi säga oss, att historiskt betraktat några få år sannolikt äro tillräckliga för att bringa arbetareklassen upp till den politiska härskareställningen." Det fanns ingen anledning att "ens motse något verkligt stillestånd i socialdemokratins frammarsch [...]. Det hela är blott en agitations- och organisationsfråga." ${ }^{51}$ Att avlägsna utskyldsstrecken var ändå viktigt, avslutade Möller, för att de - som valstatistiken visade drabbade upp till var tredje arbetare och för att de i praktiken gjorde rösträtten till en ekonomisk konjunkturfråga. ${ }^{52}$

49. Ibid.

50. Ibid., s. 197-I98, citatet s. I97.

5I. Ibid., s. 198.

52. Ibid., s. 203. 
När Möller efter en tids debatt i pressen själv sammanfattade sina syften lyfte han fram avsikten att "bevisa att socialdemokratin borde utan våldsamheter kunna inom överskådlig tid erövra den politiska makten i vårt land", att "klarlägga vägarna till detta mål", samt att "framlägga avgörande bevis för att industriarbetarnas rösträttsfråga" inte blivit löst 1907. ${ }^{53}$ Den lilla minoritet som nu dominerade politiken skulle inte kunna fortsätta att göra det om alla (manliga) arbetare fick möjlighet att delta i valen, faktiskt deltog samt konsekvent röstade i linje med sina intressen.

Den primärt reformistiska politiska strategi som Möller stod bakom fick här en till synes otvetydig grund i de realiteter som den offentliga statistiken beskrev. Utvecklingen skulle inte oundvikligen leda till kapitalismens kollaps och uppkomsten av ett socialistiskt samhälle, utan till ett demografiskt underlag för SAP att ta makten i parlamentsval och använda den till att realisera socialismen.

Möllers försök att grunda SAP:s politik och framtidsutsikter i pålitlig kunskap i en annars osäker och konfliktfylld tid gick inte obemärkt förbi. ${ }^{54}$ Bland likasinnade socialdemokrater fick han entusiastiskt om än inte helt okritiskt stöd, exempelvis i Arbetet, som tillmätte Möllers resultat "det största värde för en klar bedömning av den socialistiska demokratins framtid och vid utstakande av dess politik". 55 Även liberala Dagens Nyheter framhöll hur övertygande Möller hade visat att industriarbetarnas rösträttsfråga inte var löst. ${ }^{56}$

Möllers bearbetningar drogs också in i diskussioner om hur valstatistiken och dess kategorier kunde användas och därmed hur elektoratet kunde - eller inte kunde - begripas statistiskt. Ett antal liberala och konservativa tidningar avfärdade sarkastiskt Möllers "förkunnelse", "spå-

53. Möller i9ı8c, s. 274.

54. Undersökningen grundas i ett urval av socialdemokratiska, liberala och konservativa dagstidningar, kompletterat med sökningar i Kungliga bibliotekets samling digitaliserade dagstidningar. Möller svarade på en del av kritiken i Gustav Möller, "Fisket i valstudier", Social-Demokraten 5 september I9ı8; Möller I9ı8c. I referenslistan anför jag bara titlarna för de dagstidningar jag hänvisar till. När hänvisningar till signerade artiklar i dessa tidningar upprepas i notapparaten anges författarens efternamn och datum för publicering.

55. O. R. W, "Samhällsklassernas styrka", Arbetet 30 augusti i9i8.

56. "Klumpeduns", Dagens Nyheter I september I9I8. 
domar", "fantastiska kammarteorier" och "politiska horoskop". 57 Flera konservativa tidningar lät sig däremot synbarligen övertygas av Möllers analys, i vad flera samtida bedömare avfärdade som lätt genomskådade försök att skrämma liberalerna från att samarbeta med socialdemokraterna. ${ }^{58} \mathrm{Ur}$ ett annat perspektiv framstod Möllers "förgrovade och lindrigt sagt lättvindiga sociala gruppindelning" som föga övertygande, men han ansågs ge en värdefull inblick i Socialdemokraternas "bondefientliga" politik. ${ }^{59}$

Andra debattörer var mer specifika rörande problemen med Möllers kategorier och hur han använde dem för att dra slutsatser om den kommande politiska utvecklingen. De menade att de arbetare Möller räknade med varken hade givna eller oföränderliga intressen: jordbruksarbetarnas intressen var inte eller behövde inte vara gemensamma med industriarbetarnas, och även de redan socialdemokratiska arbetarna höll på att "växa in i det borgerliga samhället". ${ }^{60}$

Den mest genomgripande kritiken stod liberala Afton-Tidningen för. Den fann allvarliga brister i SCB:s material som Möller förde vidare, nämligen dess sortering av yrken i tre klasser. Poängen var enkel: "Klassen beror på sociala vanor, social levnadsstandard, social livssyn och socialt ursprung. Men ett och samma yrke kan uppvisa de mest skilda extraktioner, vanor, behov och åskådningar.” Därmed underminerades också möjligheten att räkna ut de olika partiernas sociala underlag, eftersom sådana uträkningar alltid började i yrkesindelningen. "Yrkena samman-

57. "Författningsfrågan", Svenska Dagbladet 4 september i9i8; "Framtidsperspektiv", Stockholms Dagblad 4 september I9I8; "Fåvitska profeter II", Sölvesborgs-Tidningen 3 oktober 1918; "Sveriges politiska framtid i statistikens ljus II", Afton-Tidningen 5 september i9i8.

58. V. L-t., "Massvälde", Aftonbladet 3 september i9ı8; "Hvem arbetar tiden för", Nya Dagligt Allehanda 3 september 1918; "Gladiatorer på frasernas arena", Nya Dagligt Allehanda 7 september I9I8; "Hos pressgrannar", Dagens Nyheter 8 september 19I8; O. R. W, "För dagen: Utan mask", Arbetet io september i9i8.

59. "Framtidsperspektiv", Stockholms Dagblad 4 september I9I8. Även "Socialister och bönder", Dalpilen ı september I918.

6o. "Verkliga framtidslinier och overkliga", Göteborgs-Posten 6 september I9ı8; "Jordbruksarbetarne", Stockholms Dagblad Io september I9I8; Fr. D-g, "Socialdemokratiens 'uppmarsch", Svenska Morgonbladet 3 september I9I8 (citatet); "En kvalfull ovisshet", Dagens Nyheter 4 september i9i8. 
falla lika litet med klasserna som med de politiska partierna”, sammanfattade tidningen. ${ }^{61}$ Problemen gick dock ännu djupare och hade att göra med Möllers förståelse av politikens natur och av hur medborgarna tog politisk ställning: "För honom är den ekonomiska intressebestämdheten på alla punkter och under alla förhållanden politiskt avgörande.” Därmed bortsåg Möller från andra faktorer av exempelvis psykologisk, religiös, nationell art, vilka var lika viktiga. När "vissa specialfrågor och akuta problem” gång på gång ställdes i den politiska stridens förgrund visade det sig att "de gamla partibanden och ännu mer klassbanden" hade en tendens att brista. "Vore det icke så", fortsatte tidningen, "skulle alla politiska strömkantringar och plötsliga opinionssvängningar vara omöjliga. Allt skulle på förhand kunna räknas ut och en mer energisk agitation vore obehövlig." Allt var inte möjligt att uttrycka i siffror: framtiden "låter sig icke [...] statistiskt framställa, då det rör levande, rörliga viljor och påverkbara personligheter”. Sannolikhetsberäkningar var inte värdelösa, men de blev "allt osäkrare, ju mer psykologiska faktorer spela in". ${ }^{62}$

Därmed hade tidningsdebatten i allmänhet och Afton-Tidningen i synnerhet återinfört en grundläggande osäkerhet och oförutsägbarhet i såväl det politiska livet som studiet av detsamma. Framtiden, inklusive medborgarnas intressen och politiska ställningstaganden, kunde inte förutsägas likt "himlafenomenens periodicitet" och sannolikhetsberäkningar var något som saknades i både den officiella valstatistikens byråkratiska siffersammanställning och Möllers användning av den. ${ }^{63}$

Afton-Tidningen psykologiska teori om medborgarna som politiska aktörer var alls inte identisk med den populära masspsykologin, men överlappade med några av dess framträdande drag. Dit hörde betoningen av att medborgarna inte var ideologiskt stabila utan hastigt ombytliga, att deras "lidelser" snabbt kunde jagas upp, och att "en allmän folkpsykos" kunde utbryta och ställa alla beräkningar på huvudet. ${ }^{64}$ Det som stod på spel var bilden av vilka väljarna var: i grunden styrda av ekonomiska "intressen" och därmed lätta att kategorisera samt stabila och pålitliga - eller flerdimensionella, fokuserade på enskilda klassöverskri-

6I. "Sveriges politiska framtid i statistikens ljus I", Afton-Tidningen 4 september I9I8.

62. "Sveriges politiska framtid i statistikens ljus II", Afton-Tidningen 5 september I9I8.

63. Ibid.

64. Ibid. 
dande frågor, psykologiskt lättrörliga och därmed oförutsägbara. Dessa olika förståelser fick konsekvenser för bruket av valstatistiken, där den i det senare fallet antogs utesluta kunskap om de dimensioner som gav politiken dess fundamentala dynamik.

För Möller utgick den avgörande kategoriseringen av valmanskåren från hans egna beräkningar av de politiskt "avgörande" folkgrupperna och från dessa urskilde han dem som Socialdemokraterna företrädde: de egendomslösa och "utsugna". Därmed förankrade han argumenten i ett teoretiskt sammanhang som fick betydligt större utrymme i SAP:s partiprogram från och med revideringen $1920 .{ }^{65}$ Det var till dessa utsugna grupper som särskild hänsyn skulle tas i partiets agitations- och organisationsverksamhet, däremot inte till bönderna. Detta var motiverat av en prioritering av partiets ändliga resurser och ett svar på samtida ambitioner att vidga cirklarna för partiets representativa anspråk.

Möllers resonemang gick, åtminstone i praktiskt hänseende, emot en sådan vidgning och sökte i stället grunda partiets snävare uppgift och identitet i de påtagligt goda framtidsutsikter som SCB:s siffror tycktes uppenbara. Detta gick inte samtida socialdemokrater förbi. I en replik till Möller argumenterade $N y$ Tid för att Socialdemokraterna inte alls borde stanna vid att vara de egendomslösas parti: "Socialdemokratin skall icke lyfta massan ur egendomslöshet och nöd för att jaga de frigjorda ifrån sig; den skall tvärtom behålla dem samtidigt som den även förvärvar anhängare i högre liggande samhällsskikt och sålunda sträva efter att erövra hela folket för sina idéer." ${ }^{\prime 66}$

\section{Per Albin Hansson och folkbegreppets fördelar, I929}

Per Albin Hanssons väg till valstatistiken hösten 1929 började med frågan om hur socialdemokratins strävanden skulle benämnas och förklaras, särskilt i agitationen. Hur lämpligt var det att tala om "klass", "klasskamp" och "klassbefrielse"? Var det inte bättre att i stället för "klass" tala om "folk"? Den "vulgära föreställningen om klasskampen" är, skrev Hansson apropå ett tal av det frisinnade partiets ledare Carl Gustaf Ekman, "envist rotad" i "det borgerliga lägret", där man "i klasskampen

65. Begreppet utsugning diskuteras utförligt i Jonsson 2000.

66. "Socialdemokratin och bondeklassen", $N y$ Tid 6 september I9I8. 
icke se något annat än en arbetarklassens strävan att tillgodose sina speciella intressen, ofta utan hänsyn till andra gruppers intressen och i strid med de allmänna intressena”. Socialdemokraterna själva hade, fortsatte han, "en betydande del i skulden till att dessa vanföreställningar uppkommit. I agitationens hetta har klasskampsterminologien blivit fruktansvärt förenklad och ofta varit mera ägna att förvilla än att reda ut begreppen". ${ }^{67}$ I sin omdebatterade ambition att just reda ut begreppen och undersöka hur politiskt användbara de egentligen var - vilket Hansson ägnade inalles sex artiklar i $N y$ Tid och en i Tiden - landade han nästan oundvikligen i valstatistiken, vilken han framhöll som det "enda försöket till officiell klassindelning vi äga". ${ }^{68}$

Det omedelbara sammanhanget till Hanssons artiklar var alltså Ekmans tal, där denne inte bara bevisat sin okunnighet om klasskampen utan därtill avfärdat tanken på ett förnyat samarbete med SAP. ${ }^{69}$ Hanssons diskussion var också djupare förankrad i partiets problem att få med sig väljarna, samt den osäkra ideologiska position partiet befunnit sig i genom hela decenniet. Det misslyckade valet 1928 motiverade en omvärdering av valagitationen, en omfattande medlemsundersökning och ovanligt utförlig statistisk valanalys. ${ }^{70}$ Något som stod klart var att den demokratisering partiet strävade efter att genomföra hade en lång väg kvar, trots utskylds- och könsstreckens borttagande ett decennium tidigare.

SAP:s partiordförande, i dag mest associerad med pragmatism och vilja till samförstånd, var vid denna tid kapabel till en radikalitet som ganska sällan blir ihågkommen. I ett tal vars betydelse i efterhand förstorats upp bortom rimliga proportioner, men som delvis anknöt till hans senare artiklar om folk och klass, visade Hansson med hjälp av officiell statistik att "socialt sett består ännu klassamhället och ekonomiskt råder fåtalets diktatur", och det var socialdemokratins uppgift att ändra på den

67. Per Albin Hansson, "Klasskampsbegrepp", Ny Tid 5 september 1929.

68. Per Albin Hansson, "Klassindelningen", Ny Tid 6 september 1929. Hanssons artiklar och Engbergs kritik har utifrån andra forskningsintressen tidigare diskuterats i exv. Karlsson 200I, s. 464-468; Jonsson 2000, s. 25I-268; Schüllerqvist I992, s. II9-I22.

69. Hansson 5 september 1929. Se vidare Jonsson 2000, s. 242, 405 not 66.

70. Se t.ex. Berman 1998, kap. 7; Schüllerqvist 1992, kap. 5 samt s. I06-IO7; Gröning I988, kap. IV särskilt s. I34-I39; valanalysen redovisades i SAP I930, s. I2-78; även Vanner 1928. 
saken. Alternativet var det Hansson ibland kallade "folkhemmet", vilket inkluderade inte bara politisk utan även social och ekonomisk demokrati - det var en levande vision vid denna tid men blev aldrig verklighet. ${ }^{7 \mathrm{I}}$

Hansson tog sin utgångspunkt i de termer som socialdemokrater vanligen använde, nämligen "borgarklass" och "arbetarklass". Dessa termer upprätthöll "vanföreställningen att skiljelinjen går mellan vad man i allmänhet förstår med kroppsarbetarklassen å ena sidan och alla andra å den motsatta sidan" ${ }^{72}$ Problemet med detta var snarlikt det som grundades i "den vedertagna populära grupperingen av människorna i överklass, medelklass och underklass" som motsvarades av valstatistikens tredelade "uppdelning av väljarna efter sociala grunder". SCB:s indelning "avslöjar svårigheterna vid en schematisk klassindelning och fäster starkt uppmärksamheten på de faror man löper, därest man drar alltför hastiga politiska o. sociala slutsatser av den populära föreställningen om klassamhället”, förklarade Hansson. Att veta hur politiskt aktiva utövarna av olika yrken var hade visserligen ett "stort både teoretiskt och praktiskt intresse". Men, fortsatte Hansson, vanskligheterna med att uppdela yrkesgrupperna i klasser genom att föra samman dem efter ekonomiskt-sociala grunder var uppenbara.

Sorteringen i tre klasser skapade därtill ur "politiska synpunkter" särskilda svårigheter. Stora delar av den officiella medelklassen röstade socialistiskt, medan åtskilliga ur det SCB kallade kroppsarbetarnas klass inte gjorde det. Därmed var det upplagt för att en "lättvindig klassindelning" kunde leda till "en felbedömning av det sociala och politiska läget och därmed av våra egna uppgifter och förpliktelser”. Inkomststatistiken förtydligade ytterligare problemet med de gränser som upprättades av valstatistikens treklassindelning; den visade exempelvis att många industriarbetare tjänade minst lika mycket som företagare, jordägare och butiksbiträden. ${ }^{73}$

Således kunde inte vedertagna uppfattningar om klassindelningen, inklusive den SCB använde, ligga till grund för "det politiska handlan-

71. Hansson i Riksdagens protokoll vid lagtima riksmötet år 1928. Andra kammaren. Band I (1928), protokoll nr 3, s. 9-2I, citatet s. II; se även Per Albin Hansson, "Vår politik", $N y$ Tid I2 september 1929. Se vidare Edling 2013; Friberg 2013.

72. Hansson 5 september 1929.

73. Hansson 6 september 1929. 
det". Socialdemokratin hade heller inte "accepterat yrkesställning eller inkomst som tillräcklig grund för klassindelningen”, förklarade Hansson med hänvisning till partiprogrammet. ${ }^{74}$ Den ur socialistisk synpunkt relevanta gränsen gick därmed "mellan det ringa fåtal, som nu behärskar de väsentligaste produktionsmedlen, och det stora folkflertal, som medvetet eller omedvetet lider under det ekonomiska fåväldet". ${ }^{75}$ Målet var därför "en samling på bredaste grund av alla antikapitalistiska element inom folket", för vilken möjligheterna också var goda. ${ }^{76}$

Begreppen "klass" och "klasskamp" var dock inte oanvändbara som grund för samhällsanalys. "Klasskamp" var fortfarande en relevant beteckning på historiska och samtida motsättningar, och det var fortfarande arbetarklassen som hade den ledande rollen i oppositionen mot det kapitalistiska systemet. Men som grund för agitationen var klassbegreppet alltför avgränsande och tyngt av missförstånd. ${ }^{77}$

I stället ställde Hansson folkbegreppet i fokus för agitationen och den "populära upplysningsverksamheten", av den anledningen att det tilltalade fler och var omedelbart begripligt. Det kunde inte råda något tvivel om att "folkbegreppet är på ett helt annat sätt samlade än klassbegreppet och att alltså även agitatoriskt det förra ger bättre resultat", förklarade han..$^{78}$ Till skillnad från "klass" fordrade inte begreppet "folk" några preciseringar, statistiska eller andra: "Gemene man" var "genast på det klara med vad som menas med folk", och begrep mycket väl vad som avsågs med "en folkets befrielse från den kapitalistiska diktaturen eller en folkresning mot det ekonomiska fäväldet" ${ }^{79}$

Den ekonomiska demokratin kunde inte "förverkligas genom beslut av en enkel majoritet", slog Hansson fast, i viss motsättning till Möllers förhoppningar ett decennium tidigare. Uppgiften krävde i stället "ett

74. Ibid.; även Per Albin Hansson, "Folk och klass", Ny Tid Io september I929.

75. Hansson 5 september 1929. Hansson definierade alltså inte klass "genom yrke och lönestatistik" som påstås i Jonsson 2000, s. 256.

76. Hansson Io september 1929 (citatet); Per Albin Hansson, "Besittande och beroende", Ny Tid 9 september 1929; Hansson 1929, s. 332-336.

77. Se särskilt Hansson 5 september 1929; även Per Albin Hansson, ”Den ledande rollen", Ny Tid 2I september I929; Hansson I929, 229-230, s. 238.

78. Hansson 5 september 1929. Jfr dock Hansson 1935, s. 69.

79. Hansson Io september 1929, även Hansson I929, s. 338. 
beslutsamt och målmedvetet folk" och det var Socialdemokraternas sak att "samla och organisera denna kraft", vilket bara kunde ske genom att "tala ett språk som folket i gemen förstår". ${ }^{\circ 0}$ Folkbegreppet överskred klasser, men inte alla klasser: de "stora kapitalistiska produktionsmedlens ägare" tillhörde inte Hanssons "folk" och skulle inte ingå i samarbetet för att avskaffa kapitalismen. ${ }^{8 \mathrm{I}}$ "Folket" skulle kunna bestämmas statistiskt, exempelvis utifrån valstatistiken, men i praktiken behövde det inte preciseras. De kunskaper och kategorier valstatistiken bidrog med var snarast kontraproduktiva eftersom de drog upp politiskt irrelevanta och vilseledande gränser mellan väljare med i grunden gemensamma intressen.

Hanssons argumentation väckte en hel del intresse på socialdemokratiska ledarsidor, bland vilka Skånska Socialdemokraten och dess redaktör Karl Bergström tillhörde dem som starkast stödde Hanssons prioritering av folkbegreppet framför klassbegreppet. Tidningen gick till och med längre än Hansson själv, och argumenterade för att klasskampsterminologin inte bara var olämplig som utgångspunkt för agitationen utan mer allmänt var förvirrande och otidsenlig och därmed "en spärr för rörelsens vidare utveckling och förkovran" ${ }^{82}$ Arthur Engberg, redaktör för Social-Demokraten, riksdagsledamot och allmänt känd som en av partiets teoretiker, invände mycket utförligt mot den position Skånska Socialdemokraten intog, liksom mot Hansson själv. Beväpnad med såväl partiprogrammet som Marx och Kautsky argumenterade Engberg för att "klass" inte kunde ersättas med "folk", varken som grund för en samhällsförståelse eller i agitationen. ${ }^{83}$

I detta syfte publicerade Engberg en serie begreppsutredande artiklar, vilka också drog in den officiella statistikens kategorier i diskussionen. Särskilt problematiskt med den pågående debatten var, framhöll Engberg, att klassbegreppet användes på många olika sätt, vilket gjort

80. Hansson 12 september 1929.

8I. Hansson Io september 1929. Hansson framhöll explicit att det inte fanns någon motsättning mellan arbetarklassens intressen och allmänna intressen, se t.ex. Hansson 2I september I929; jfr Jonsson 2000, s. 256-257.

82. Se särskilt "Klassparti eller folkparti", Skånska Socialdemokraten 7 september 1929 (citatet); "Klass eller folkbefrielse", Skånska Socialdemokraten I7 september I929; "Det gäller en verklig folkbefrielse", Skånska Socialdemokraten 20 september 1929.

83. Om relationen mellan Hansson och Engberg, se exv. Karlsson 200I, kap. IX. 
att "meningsutbytet om socialdemokratins karaktär och dess ställning till klasskampen" blivit "en ren cirkus". ${ }^{84}$ "Klass" kunde inte avse vilken grupp som helst, utan "vad som gör en grupp till en klass är helt enkelt detta att den förhåller sig till en annan grupp som utsugare eller utsugen och antingen söker befästa eller upphäva ett slikt förhållande"; det krävdes en "motpol" och ett "motsatsförhållande". ${ }^{85}$

Engberg avfärdade treklassindelningen och räknade i stället med två klasser - kapitalistklassen och arbetarklassen - samt däremellan ett antal "sociala grupper" (exempelvis småbönder). Målet var givetvis att dessa skulle ta arbetarklassens sida då de insett att det låg i deras intresse, något som onekligen liknade Hanssons ståndpunkt men med den skillnaden att det inte fanns någon anledning att beteckna eller tilltala en sådan antikapitalistisk samling som "folket". ${ }^{86}$

Konsekvensen av detta resonemang var att valstatistikens liksom inkomst-, förmögenhets- eller befolkningsstatistikens kategorier var oanvändbara för att förstå samhällets relevanta konfliktlinjer och därmed inte heller kunde vara till någon ledning för socialdemokratins politiska arbete. Trots att Engberg inte ville samla alla de grupper som stod emot kapitalistklassen under beteckningen "folket" - och därmed inte hade samma anledning att bekymra sig över onödigt splittrande kategoriseringar - hamnade han alltså när det gällde den statistiska kunskapen på en liknande position som Hansson.

Engberg och Hansson var överens om att, som den senare skrev, "beteckningarna spela en betydande roll" och kunde såväl möjliggöra som förhindra önskvärda politiska handlingsvägar. ${ }^{87}$ Engberg tillstod att hans begreppsutredningar kunde verka småaktiga, men ansåg att det var viktigt att "gå begreppen in på livet för att visa upp deras verkliga karaktär." Målet var "att nå saklig klarhet", inget annat. Det var, fortsatte han, "en gammal god regel även beträffande slagorden, att man gör klokt i att

84. Artur Engberg, "Klassbefrielse, klassamling, klasskamp", Social-Demokraten II september 1929 .

85. Artur Engberg, "Vad menas med klass?", Social-Demokraten I2 september I929; Artur Engberg, "Väsentligt och oväsentligt", Social-Demokraten I3 september 1929.

86. Engberg I3 september 1929; Artur Engberg, "Uppställningen", Social-Demokraten I4 september 1929; Artur Engberg, "Folkhemmet", Social-Demokraten I5 september 1929. 87. Hansson 5 september 1929; även exv. Hansson 1929, 338; "Klass eller folkbefrielse", Skånska Socialdemokraten 17 september 1929. 
noga mönstra dem, innan man släpper in dem till att härja i begreppsoch åsiktsbildningens rabatter" ${ }^{88}$

Båda skribenterna förankrade begreppsdiskussionen primärt i frågan om vilka termer som skulle användas för att mobilisera väljare, men medan Hansson och än mer andra skribenter i den socialdemokratiska pressen förlitade sig på det omedelbart begripliga, folkbegreppets "patos" eller att "appellera till människors instinkt", så föredrog Engberg precision, klarhet och saklighet framför suggestion, även i agitationen. ${ }^{89}$ Därmed framställde de även motsatta uppfattningar om hur väljarna var beskaffade och vad som kunde få dem att stöda socialdemokratisk politik. Vem som hade rätt i detta kunde inte valstatistiken bidra till att avgöra, och för ingen av dem var valstatistiken och dess kategorisering av elektoratet särskilt användbar: den hjälpte dem inte ringa in eller hitta det rätta sättet att tilltala det folk eller de klasser som måste sluta upp på socialdemokratins sida. Att det, särskilt för Hansson, var viktigt att utförligt visa detta tydliggör samtidigt den tyngd som valstatistiken, med dess officiella klassindelning och kunskapsframställning om det väljande folket, tillskrevs i tidens politiska kultur.

\section{Politiska siffror i en föränderlig tid}

Den period som undersökningen rört sig i var säregen i svensk historia, men också den tid - som Göran Therborn framhållit - då den svenska politiken som mest liknade den övriga västeuropeiska. I en tid av genomgripande politisk osäkerhet utvidgades rösträtten och parlamentarism infördes, varefter följde ett decennium då arbetarrörelsen tycktes stagnera samtidigt som arbetsmarknadskonflikterna och minoritetsregeringarna avlöste varandra i rask takt. ${ }^{90}$ Demokratin var här mindre ett definitivt uppnått tillstånd och mer ett öppet och oavslutat projekt. Detta gällde inte minst för SAP, som vid sidan av den politiska demokratin strävade efter att genomföra social och ekonomisk demokrati.

88. Engberg I5 september I929.

89. Det två första citaten ur Allan Vougt, "En strid utan meningsskillnad", Arbetet $\mathrm{I} 3$ september 1929, det tredje ur "Sagt och skrivet", Arbetet IO september 1929; Engberg I5 september 1929.

90. Therborn I984, s. 20. 
Valstatistiken var involverad i den politiska demokratiseringen genom dess deklarerade syfte att ge underlag för bedömningen av genomförda reformer och för utformandet av nya. Den blev också involverad i demokratiseringen och mer allmänt i utvecklingen av den politiska kulturen eftersom den kunde bearbetas i syfte att underbygga politiska prioriteringar av reformförslag, budskap och valstrategier. Inte ens valstatistiken kunde bidra med definitiva och okontroversiella framställningar av demokratins folk.

För SAP innebar detta att valstatistiken drogs in i en process där partiets representativa anspråk omförhandlades och successivt utvidgades. I händerna på entusiastiska partiföreträdare erbjöd valstatistiken inte i första hand en färdig, politiskt neutral, byråkratisk blick på elektoratet. Snarare behandlades valstatistiken som ett ofullkomligt redskap att tänka med, ett redskap som kunde omarbetas, kritiseras och sättas i bruk. Inte heller detta var en slutstation för valstatistikens cirkulering, utan bearbetningarna och slutsatserna kunde fortsätta att diskuteras, kritiseras och avfärdas. Den totalinventering av elektoratet som SCB genomförde och publicerade möjliggjorde en position av suverän överblick för medlemmar av SAP:s ledarskikt, men det var en överblick som också användes i partiets valmaterial för att låta potentiella väljare få syn på sin egen relation till elektoratet som helhet och därmed betydelsen av valdeltagande på arbetarpartiets sida.

Valstatistikens former medförde begränsningar som inte gick att komma runt och innehöll kategorier som inte kunde brytas upp. Partiernas stöd inom olika grupper kunde den inte kartlägga, och medan dess klasskategorier kunde göras om eller avfärdas låg dess yrkeskategoriseringar fast och bildade närmast oundvikligen grund för vidare omarbetningar och studier av valdeltagandet. Men trots sina begränsningar möjliggjorde valstatistiken analyser, politiska reflexioner och argumentationslinjer som annars var svåra eller omöjliga att göra med samma tyngd och tillförlitlighet. Ingenting kunde med samma otvetydiga säkerhet visa konsekvenserna av kvarvarande rösträttsstreck och behovet att avlägsna dem. Valstatistiken gav också trovärdighet åt försöken att finna stabilitet, förutsägbarhet och hopp i en osäker och konfliktfylld tid, vilket Möllers optimistiska uträkningar och liknande sammanställningar i valarbetet är exempel på. Vidare underbyggde den kritiska självreflexioner och slut- 
satser kring vilka grupper partiet borde prioritera, hur valarbetet borde läggas upp samt hur partiet borde förstå och använda centrala politiska kategorier såsom "klass" och "folk". Detta kreativa om- och nyskapande arbete både utgick från och bidrog till att forma explicit politiskt orienterade samhällsanalyser; det var ett arbete där vetande om väljare, politiska kategorier och partistrategiska överväganden var i rörelse samtidigt och tilläts informera varandra.

Elektoratet blev begripligt och överskådligt på nya sätt med valstatistikens siffror, men bruket av dem fordrade också föregående föreställningar om hur väljarna var beskaffade, inte minst i termer av vad som var deras egentliga intressen. I linje med en i bred mening historiematerialistisk utgångspunkt antogs dessa intressen vara socialt och ekonomiskt determinerade, men valstatistiken tydliggjorde att väljarnas faktiska agerande i valen inte var det.

Även Hansson tillstod att valstatistikens meddelanden om i vilken utsträckning olika yrkesgrupper röstade var användbara, och partiets eftervalsanalyser visar också att valstatistiken togs på stort allvar fortsättningsvis. Men i och med Hanssons argument för att ersätta "klass" med "folk" i partiets utåtriktade verksamhet blev den noggranna omarbetningen av valstatistikens kategoriseringar i detta fall politiskt irrelevant. En sådan omarbetning kunde inte som för Sandler eller Möller ge någon vägledning för partiets övergripande strategi, som nu gällde att under beteckningen "folket" tilltala och samla alla som inte tillhörde det ekonomiska fåväldet.

Hansson lanserade andra representativa anspråk: genom att tilltalas som ett folk skulle detta folk bli till av en mängd olika grupper som för närvarande - delvis på grund av det slags ogrundade treklasschema som bland annat valstatistiken använde sig av - uppfattade sig som skilda åt. Till skillnad från Sandler, Möller och även Engberg formulerade Hansson SAP:s exklusiva anspråk på att representera hela "folket" och dess allmänna intressen gentemot den lilla elit som härskade med endast egenintresset för ögonen - och då fanns åtminstone i agitationen ingen anledning att dra upp gränser inom folket.

I den politiskt öppna och osäkra tiden under det tidiga 1900-talet är det inte förvånande att politiska partier ägnade stor uppmärksamhet och intellektuell energi åt de konkreta och pålitliga kunskaper om det nya 
och föränderliga elektoratet som faktiskt fanns tillgängliga. Mer förvånande är möjligen att så lite historisk forskning ägnats åt att undersöka hur detta skedde och med vilka målsättningar, konsekvenser och begränsningar. Det var en politisk kultur som alltmer grundades i ett kvantitativt vetande om väljare, vilket tillsammans med rundfrågor och tidningsstudier föregrep efterkrigstidens upptagenhet vid opinionsundersökningar och samhällsvetenskaplig väljarforskning.

Det förefaller angeläget att förståelsen av de politiska partiernas inte minst arbetarpartiernas - såväl programmatiska som mer valtaktiska förändringar förankras i hur kvantitativ kunskap om väljare togs i bruk. Samtidigt måste intresset även riktas mot de andra kunskapsformer som utvecklades parallellt. Som debatterna om Möllers och Hanssons artiklar antyder kunde också en annan typ av vetande än statistisk ställas i förgrunden. En socialdemokratisk debattör framhöll: "politik är ju tilllämpad psykologi". ${ }^{\mathrm{I}} \mathrm{Vilka}$ var egentligen människornas instinkter som man kunde appellera till? Hur fungerade suggestion? Vad fick människor att uppmärksamma ett budskap? Det var frågor som de psykologiska vetenskaperna - inklusive den nya "reklampsykologin" - snarare än valstatistiken, gjorde anspråk på att besvara.

\section{Referenser}

Dagstidningar

Aftonbladet

Afton-Tidningen

Arbetet

Dagens Nyheter

Dalpilen

Göteborgs-Posten

Ny Tid

Nya Dagligt Allehanda

Skanska Socialdemokraten

Social-Demokraten

Stockholms Dagblad

Svenska Dagbladet

Svenska Morgonbladet

Sölvesborgs-Tidningen

9I. Vougt I3 september I929. 


\section{Övriga källor}

Berg, Fredrik Theodor (I870) "Utkast till en plan för Sveriges officiella statistik", Statistisk tidskrift hft 24-27.

Hansson, Per Albin (1929) "Folk och klass", Tiden nr 6.

Hansson, Per Albin (1935) Demokrati. Stockholm.

Möller, Gustav (I918a) "Studier i valstatistiken", Tiden nr 5.

Möller, Gustav (I9I8b) "Den sociala revolutionen", Tiden nr 6.

Möller, Gustav (I9I8c) "Illusionsfri politik", Tiden nr 6.

Riksdagens protokoll vid lagtima riksmötet år I928. Andra kammaren. Bd I (1928) Stockholm.

Sandler, Rickard (iэıг) Sambället sådant det är. Statistiska uppgifter om land och folk, produktion och fordelning. Stockholm.

Sandler, Rickard (I9IIb) Miljonärernas samhälle. En skildring för valmännen. Stockholm. Sandler, Rickard (I9I2a) "Valmanskåren. Reflexioner till valstatistiken. I", Tiden nr 8.

Sandler, Rickard (I9I2b) "Valmanskåren. Reflexioner till valstatistiken. II", Tiden nr 8.

Sandler, Rickard (I9I2c) "Parti och valmanskår", Tiden nr Io.

SAP (1922) Socialdemokratiska partistyrelsens berättelse för år I92I. Stockholm.

SAP (1924) Arbetarpartiet kan segra! Vad valstatistiken lär. Stockholm.

SAP (1930) Socialdemokratiska partistyrelsens berättelse för år 1928. Stockholm.

SCB (I873) Valstatistik. Statistiska Central-byråns underdåniga berättelse rörande riksdagsmanna-valen air 1872 . Stockholm.

SCB (I9I2) Riksdagsmannavalen åren I909-I9II. Stockholm.

Vanner, Alfred (1928) "Riksdagsvalet", Tiden nr 6.

\section{Litteratur}

Alonso, William \& Paul Starr (1987) "Introduction”, i William Alonso \& Paul Starr, red., The politics of numbers. New York.

Beers, Laura (2OII) "Polling public opinion before opinion polls. The conservative party and election prediction between the wars", i Tom Crook \& Glen O'Hara, red., Statistics and the public sphere. Numbers and the people in modern Britain, c. I800-2000. New York.

Berger, Stefan (1995) "European labour movements and the European working class in comparative perspective", i Stefan Berger \& David Broughton, red., The force of labour. The Western European labour movement and the working class in the twentieth century. Oxford.

Berman, Sheri (1998) The Social Democratic moment. Ideas and politics in the making of interwar Europe. Cambridge.

Black, Lawrence (2003) "'What kind of people are you?' Labour, the people and the 'new political history", i John Callaghan, Steven Fielding \& Steve Ludlam, red., Interpreting the labour party. Approaches to labour politics and history. Manchester.

Canovan, Margaret (2005) The people. Cambridge.

Childers, Thomas (1990) "The social language of politics in Germany. The sociology of political discourse in the Weimar Republic", The American Historical Review nr 2. DoI: https://doi.org/IO.I086/ahr/95.2.33I 
Crook, Tom \& Glen O'Hara, red. (2011) Statistics and the public sphere. Numbers and the people in modern Britain, c. I800-2000. New York.

Dannefjord, Per (2009) Organisationspraktiker och målförändring. Exemplet svensk socialdemokrati. Lund.

de Jong, Wim \& Harm Kaal (2017) "Mapping the demos. The scientisation of the political, electoral research and Dutch political parties, c. 1900-1980", Contemporary European History $\mathrm{nr}$ I.

DoI: https://doi.org/I0.I0I7/So960777316000515

Edling, Nils (2013) "The primacy of welfare politics. Notes on the language of the Swedish Social Democrats and their adversaries in the I930s", i Heidi Haggrén, Johanna Rainio-Niemi \& Jussi Vauhkonen, red., Multi-layered historicity of the present. Approaches to social science history. Helsingfors.

Frank, Jason (2010) Constituent moments. Enacting the people in postrevolutionary America. Durham.

Friberg, Anna (2013) Demokrati bortom politiken. En begreppshistorisk analys av demokratibegreppet inom Sveriges socialdemokratiska arbetareparti 19I9-1939. Stockholm.

Gröning, Lotta (1988) Vägen till makten. SAP:s organisation och dess betydelse för den politiska verksamheten I9oo-I933. Uppsala.

Hilson, Mary (200I) "Swedish approaches to the rise of labour. A British perspective", Scandianvian Journal of History $\mathrm{nr} 2$.

DOI: https://doi.org/10.1080/034687501750211136

Igo, Sarah E. (2007) The averaged American. Surveys, citizens, and the making of a mass public. Cambridge.

Jansson, Jenny (2012) Manufacturing consensus. The making of the Swedish reformist working class. Uppsala.

Jonsson, Tomas (2000) "Att anpassa sig efter det möliga". Utsugningsbegreppet och SAP:s ideologiska förändringar I9II-I944. Göteborg.

Kaal, Harm (2013) "Constructing a socialist constituency. The Social Democratic language of politics in the Netherlands, c. 1890-1950", Archiv für Sozialgeschichte band 53.

Karlsson, Sten O. (200I) Det intelligenta sambället. En omtolkning av socialdemokratins idéhistoria. Stockholm.

Källström, Staffan (I995) Om barbarers tämjande. Stockholm.

Lawrence, Jon (20II) "Labour and the politics of class, I900-I940", i David Feldman \& Jon Lawrence, red., Structures and transformations in modern British history. Cambridge.

Le Bon, Gustave (I9I2) Massans psykologi. Stockholm.

Lewin, Leif, Bo Jansson \& Dag Sörbom (1972) The Swedish electorate 1887-1968. Stockholm.

Linderborg, Åsa (200I) Socialdemokraterna skriver historia. Historieskrivning som ideologisk maktresurs I892-2000. Stockholm.

Lindgren, Mattias (2019) "Hur många har saknat rösträtt i den svenska demokratin?", Arbetarhistoria nr 2-3.

Lundberg, Viktor (2007) Folket, yxan och orättvisans rot. Betydelsebildning kring demokrati i den svenska rösträttsrörelsens diskursgemenskap, I887-1902. Umeå. 
Müller, Jan-Werner (2016) What is populism? Philadelphia.

Norman, Torbjörn (2000-2002) "Rickard J Sandler", i Svenskt biografiskt lexikon, band 3I. URL: https://sok.riksarkivet.se/sbl/artikel/6346 (I8 maj 2020)

Olson, Kevin (2016) Imagined sovereignties. The power of the people and other myths of the modern age. Cambridge.

Rosanvallon, Pierre (2006) Democracy past and future. New York.

Rosanvallon, Pierre (20II) Democratic legitimacy. Impartiality, reflexivity, proximity. Princeton.

Rose, Nikolas (1999) Powers of freedom. Reframing political thought. Cambridge.

Rönnbäck, Josefin (2004) Politikens genusgränser. Den kvinnliga rösträttsrörelsen och kampen för kvinnors politiska medborgarskap 1902-I92I. Stockholm.

Saward, Michael (2006) "The representative claim", Contemporary Political Theory nr 3. DOI: https://doi.org/IO.IO57/palgrave.cpt.9300234

Schröder, Benjamin (2015) "Wer ist Freund, wer Feind? Parteien und Wähler in politischer Unsicherheit", i Tim B. Müller \& Adam Tooze, red., Normalität und Fragilität. Demokratie nach dem Ersten Weltkrieg. Hamburg.

Schüllerqvist, Bengt (1992) Från kosackval till kohandel. SAP:s väg till makten (1928-33). Stockholm.

Simonson, Birger (1985) Socialdemokratin och maktövertagandet. SAP:s politiska strategi I889-I9II. Göteborg.

Stråth, Bo (1986) "Socialdemokratisk ideologi mellan utopi och verklighet", Arkiv för studier i arbetarrörelsens historia $\mathrm{nr}$ 34-35.

Therborn, Göran (1984) "Den svenska socialdemokratin träder fram”, Arkiv för studier $i$ arbetarrörelsens historia $\mathrm{nr}$ 27-28.

Tilton, Tim (1990) The political theory of Swedish Social Democracy. Through the welfare state to socialism. Oxford.

Tingsten, Herbert (1937) Political behavior. London.

Tistedt, Petter (2013) Visioner om medborgerliga publiker. Medier och socialreformism $p a$ I930-talet. Höör.

Tistedt, Petter (2019) "Knowing the demos. Gender and the politics of classifying voters in the aftermath of universal suffrage", Scandianvian Journal of History $\mathrm{nr} 3$. DoI: https://doi.org/Io.Io8o/03468755.2018.1507925

Tistedt, Petter (2020) "Folket i siffror. Den svenska valstatistikens politik, I866-I92I", Historisk tidskrift $\mathrm{nr} 2$.

Wring, Dominic (2005) The politics of marketing the labour party. Basingstoke.

Östling, Johan m.fl., red. (20I8) Circulation of knowledge. Explorations in the history of knowledge. Lund. 


\section{Läs de tidiga svenska socialdemokraternas egna texter i Arkiv klassikerserie}

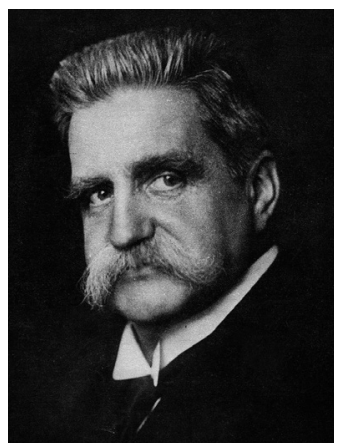

Hjalmar Branting

Stridsfrågor inom arbetarrörelsen

(1979 [texter från 1889-1917])

August Palm

Ur en agitators liv

(1983 [1905])

Axel Danielsson

Politiska skrifter $i$ urval (1983 [1908])

Socialismens grundvalar. En diskussion å Folkets Hus den 7 februari 1908 (1979 [1908] med Hjalmar Branting, C N Carleson \& Zeth "Zäta” Höglund)

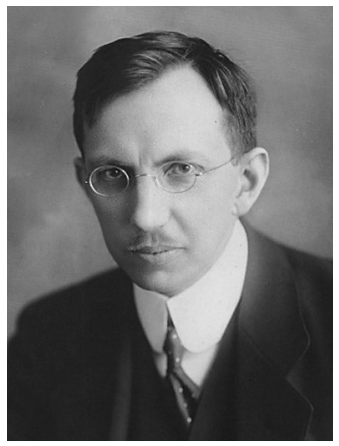

Zeth "Zäta” Höglund, Hannes Sköld \& Fredrik Ström (red.) Det befästa fattighuset. Antimilitaristisk och socialistisk handbok (1979 [1913])

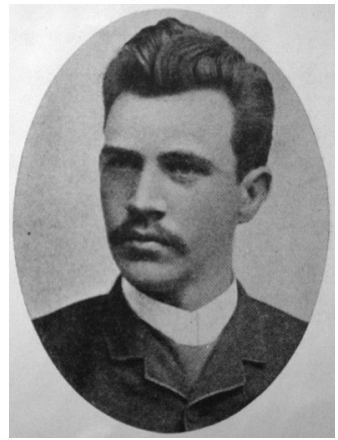

Einar "Texas" Ljungberg På uppviglarstråt. Färdminnen (1979 [1917])

»Läs mer om böckerna på www.arkiv.nu« 